\title{
DEVELOPING AN INNOVATION MANAGEMENT TEACHING MODEL
}

\author{
Tai-Ho Yang ${ }^{1}$, Chin-Chiuan Lin ${ }^{2}$ \\ ${ }^{1}$ Department of Business Administration, Kun Shan University, Tainan, Taiwan \\ Email:mkc@mail.ksu.edu.tw \\ ${ }^{2}$ Department of Business Administration, Kun Shan University, Tainan, Taiwan \\ Email: cclin@mail.ksu.edu.tw
}

Masuk : 30-06-2020, revisi: 03-07-2020, diterima untuk diterbitkan : 06-07-2020

\begin{abstract}
ABSTRAK
Penelitian ini bertujuan untuk mengembangkan model pengajaran manajemen inovasi (IMT) yang mencakup tanggung jawab sosial universitas (USR) dan pembelajaran berbasis masalah (PBL) menggunakan proyek USR yang diselenggarakan oleh penulis selama dua tahun terakhir. Setelah dua tahun dilakukan. Hasil menunjukkan bahwa siswa yang berpartisipasi dalam model IMT dapat meningkatkan motivasi belajar mereka, rasa prestasi, dan rasa hormat. Selanjutnya, beberapa masalah objek regional (kabupaten Guantian) juga dapat diselesaikan setelah melakukan proyek USR.
\end{abstract}

Kata Kunci: IMT, USR, PBL.

\section{ABSTRACT}

This study aimed to develop an innovation management teaching (IMT) model which included university social responsibility (USR) and problem-based learning (PBL) using a USR project that hosted by the authors during recent two years. After two years performed. Results showed that the students who participate in the IMT model can enhance their learning motivation, sense of accomplishment, and sense of honour. Furthermore, some problems of the regional object (Guantian district) also can be solved after perform the USR project.

Keywords: IMT, USR, PBL.

\section{INTRODUCTION}

In recent years, the Ministry of Education (MOE) of Taiwan has been committed to the development and promotion of innovative teaching methods in many fields. university social responsibility (USR) and problem-based learning (PBL) are the two most ubiquitous topics of the innovative teaching methods. USR is the social responsibility which concerned with universities, and PBL is a student centered pedagogy in which students learn about a subject through the experience of solving an open-ended problem found in trigger material. The USR and PBL have the same corcerned about students, that is the students were all playing a major role in both program. Therefore, the present study aimed to develop an IMT model which included USR, PBL, teachers and students, and demonstration by a USR project. The object of the USR project is the Guantian district. The PBL was set up by a new course "business ethics" of department of business administration. The university students and teashers were the students and teashers of Kun Shan University (KSU). Figure 1 shows the architecture of the IMT model.

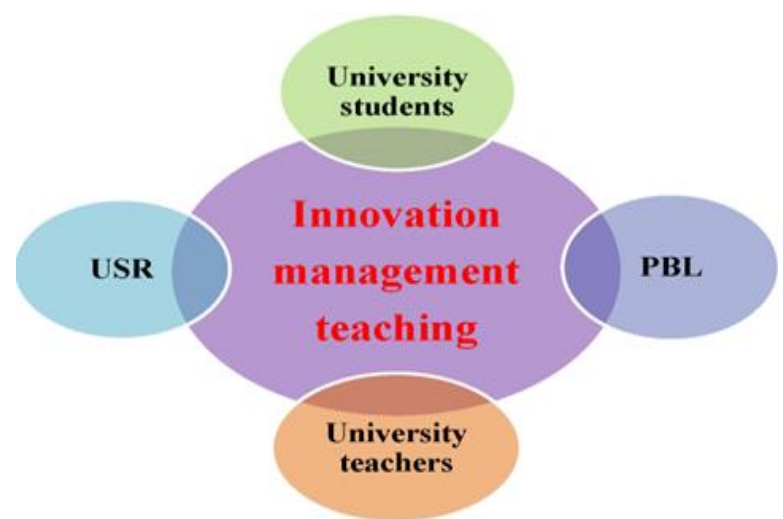

Figure 1. Architecture of the IMT model. 


\section{LITERATURE REVIEW}

\section{Definition and Conception of USR}

Nowadays university's function is not only training various vocations and then issuing diplomas, but also help students finding their sense of direction and think beyond individual interest to societal interest (Vasilescu et al., 2010). Reiser (2007) defined USR as the ethical performance of the university through the responsible management of various impacts of the university in interaction with society to improve human development. Esfijani et al. (2013) concluded that the concept of USR, it can be inferred the social responsibility of a university can be seen through its partnership with its stakeholders. Vasilescu et al. (2010) indicated that one of the main aims of USR is to develop a sense of civil citizenship in order to achieve global sustainable development.

Esfijani et al. (2013) concluded that in a socially responsible university there is a continuing commitment to address community problems through knowledge production, nurturing active and engaged citizens, contributing to social change, considering moral values, high quality service provision which finally results in a sustainable development. Esfijani et al. (2013) also developed an USR ontology, there are seven notions associated with USR by which the concept has been defined through the literatures. The seven notions are engagement, education, research, service, ethics, transparency, and stakeholders. Stewart (2004) proposed that the issues of social responsibility in education constitute content preparation for designing appropriate programs which aim to train students for various vocations, as well as ensuring that under-served populations have access to these programs.

However, no published work has been found that presents a global unified understanding of university social responsibility (Esfijani et al., 2013). Carroll (1979) distinguishes 4 main components of the conceptions of social responsibility: (1). the economic component represents the obligation to produce goods and services, that society wants and to sell them at a profit. (2). the legal component is determined by the laws and regulations under which firm is expected to operate. (3). the ethical component includes additional activities and behaviours that are not codified into law but nevertheless are expected of business by society. (4). the discretionary component represents volitional or philanthropic activities.

Ayala-Rodríguez et al. (2019) proposed new paradigms of USR conceive students as key players who express their beliefs, attitudes and opinions both in the professional training process and in their willingness to serve the community, and concluded that the USR is an issue related to the internal and external of universities in social environments and the policies they approach and solve the social problems of the communities. Ayala-Rodríguez et al. (2019) also showed that the perceived USR by student context incorporate the historical of the traditional positions and anchored to the collective memory. Nevertheless, it is important to note that the "prosocial sense" category, defined as actions that are performed voluntarily for the benefit of others.

Sánchez-Hernández and Mainardes (2016) concluded that there is a positive relationship between the participate of USR with the students' satisfaction and social entrepreneurship culture after the statistical analysis procedure applied to a sample of 392 students in courses devoted to Business Management at the university in Brazil. Table 1 summarized the alternative conceptions of social responsibility.

Table 1. Alternative conceptions of social responsibility

\begin{tabular}{cl}
\hline Study & Conceptions of Social Responsibility \\
\hline Bowen (1953) & $\begin{array}{l}\text { Businessmen have an obligation to pursue those policies, to make those decisions, or to follow } \\
\text { those lines of action which are desirable in terms of the objectives and values of our society. }\end{array}$
\end{tabular}




\begin{tabular}{ll}
\hline Davis (1960) & $\begin{array}{l}\text { Businessmen's decisions and actions taken for reasons at least partially beyond the firm's } \\
\text { direct economic or technical interest. }\end{array}$ \\
\hline Carroll (1979) & $\begin{array}{l}\text { Encompasses the economic, legal, ethical, and discretionary expectations that society has of } \\
\text { organizations at a given point in time. }\end{array}$ \\
\hline $\begin{array}{l}\text { Wartick \& } \\
\text { Cochran (1985) }\end{array}$ & $\begin{array}{l}\text { Business exists at the pleasure of society; its behaviour and methods of operation must fall } \\
\text { implied set of rights and obligations. }\end{array}$ \\
\hline $\begin{array}{l}\text { Perdiguero } \\
\text { (2006) }\end{array}$ & $\begin{array}{l}\text { The new concept of responsibility is related to the civil responsibilities of the individual and to } \\
\text { assuming responsibility at a global level for the consequences of collective action. }\end{array}$ \\
\hline
\end{tabular}

\section{USR in Taiwan}

The universities have been obtained many public resources and able to gather the elites from various professional fields. However, the expectation and accountability about the USR have become higher and higher in recent years. The university's teachers and students in addition to continuing research and innovation in their own fields, they should combine of industrial development and the prosperity of region communities through implement the USR project.

Therefore, the university's inclusion the social responsibility as an important project for school development has become a global trend, further, the EU has also proposed the structure for university social responsibility. The MOE of Taiwan in order to strengthen the links between region communities and universities. Thus, introduced USR projects and cultivate universities students who can create value for region development.

The USR projects have been launched since 2017, and in 2018, the "higher education deep cultivation (HEDC) project" was also linked with the USR project. Furthermore, properly response to social responsibility is the major goal of the HEDC project. Encourage all universities to propose their USR project with the core concept of connecting with the community needs and cultivating students' talents. Through the social care and assistance to solve the problems of community needs based on people-orientation.

The core value of the USR project is to make the university an active participant and contributor to region community sustainable development. Therefore, the key elements of USR include talent cultivation, regional linkage, and social innovation. The university cultivates talents and retained in the region, so that all sectors can see hope together, find ways to realize hope, and improve opportunities for sustainable development of region community.

Overall, the USR project is a program that combines teaching innovation with social practice to improve the gap of learning. It is also a university that assists in solving the problem of social and economic development, and thus promotes students' recognition of the local community and the plan to start a business on the region. It is also a program that connects the world to the future and to contribute to global sustainable development.

\section{RESEARCH METHODS}

\section{PBL with USR}

Wood (2003) defines problem-based learning (PBL) as a process that uses identified issues within a scenario to increase knowledge and understanding. Wood (2003) also indicated that in PBL students use "triggers" from the problem case or scenario to define their learning objectives. Subsequently they do independent, self directed study before returning to the group to discuss and refine their acquired knowledge. Thus, PBL is not about problem solving, but rather it uses appropriate problems to increase knowledge and understanding. Therefore, problem based learning is focus on the tutorial and learning process rather than problem solving with a defined 
solution. The problem BL process was pioneered by Barrows and Tamblyn (1980) at the medical school program at McMaster University in Hamilton.

The process is clearly defined, and the several variations that exist all follow a similar series of steps:

(1) Identify and clarify unfamiliar terms presented in the scenario; scribe lists those that remain unexplained after discussion.

(2) Define the problem(s) to be discussed; students may have different views on the issues, but all should be considered; scribe records a list of agreed problems.

(3) Brainstorming session to discuss the problem(s), suggesting possible explanations on basis of prior knowledge; students draw on each other's knowledge and identify areas of incomplete knowledge; scribe records all discussion.

(4) Review steps 2 and 3 and arrange explanations into tentative solutions; scribe organizes the explanations and restructures if necessary.

(5) Formulate learning objectives; group reaches consensus on the learning objectives; tutor ensures learning objectives are focused, achievable, comprehensive, and appropriate.

(6) Private study (all students gather information related to each learning objective).

(7) Group shares results of private study (students identify their learning resources and share their results); tutor checks learning and may assess the group.

Nowadays universities conducted PBL in many teaching areas, such as medical, management, and engineering,... etc. Furthermore, we can infer that the PBL is one of the efficiency teaching method that help teachers and students to execute the USR projects.

\section{RESULTS AND DISCUSSION}

\section{Background}

The object of the USR project is the Guantian district which near the Kun Shan University (KSU). It focuses on the link to the region and emphasizes to solve the regional problems. And the vision of this USR project is the prosperity and development of Guantian district. For the purpose to perform the USR project, the Dean of Collage of Business and Management of KSU established an interdisciplinary team, and the members are included teachers and students from the department of business administration, visual communication, accounting information, and public relations and advertising.

\section{Problems}

After consulting with stakeholders of Guantian district in Tainan city, it is found 4 main problems (challenges) can be summarized as follows:

(1) Discard shell of water caltrop: Guantian district produces 6,800 tons of water caltrops per year which is also associated with the production approximately 3,700 tons of waste (water caltrop shell). The shell of the water caltrop is hard and difficult to treated. Farmers often used incineration to cause environmental problems such as air pollution.

(2) Ecological pollution: Pheasant-tailed Jacana is the second level conservation wildlife and has been widely distributed in the plain wetlands. However, the pheasant-tailed Jacana prefers the water caltrop fields, the Guantian district produce more $70 \%$ of water caltrop in Taiwan. However, the water caltrop formers usually excessive use of pesticides. Thus, cause the collective poisoning death of the pheasant-tailed Jacana from 2009 to 2010.

(3) Aging population: The population of Guantian district is 21,535 and the number of elderly people over 65 years old is 3,511, about $16 \%$ of the population, and the Palin community of Guantian district is $24 \%$. 
(4) Manpower outflow: Agriculture is the main industry in Guantian district. The main products include: rice, water caltrop, mango and so on. However, due to lack of high value-added agricultural products, it is difficult to retain young man.

Left side of the Figure 2 shows the 4 main problems of the USR project. The middle of the Figure 2 shows the strategies which can be conduct to solve the 4 main problems of the USR project. The core concept, strategies and action plans were described in section 3.3 and section 3.4 , respectively.

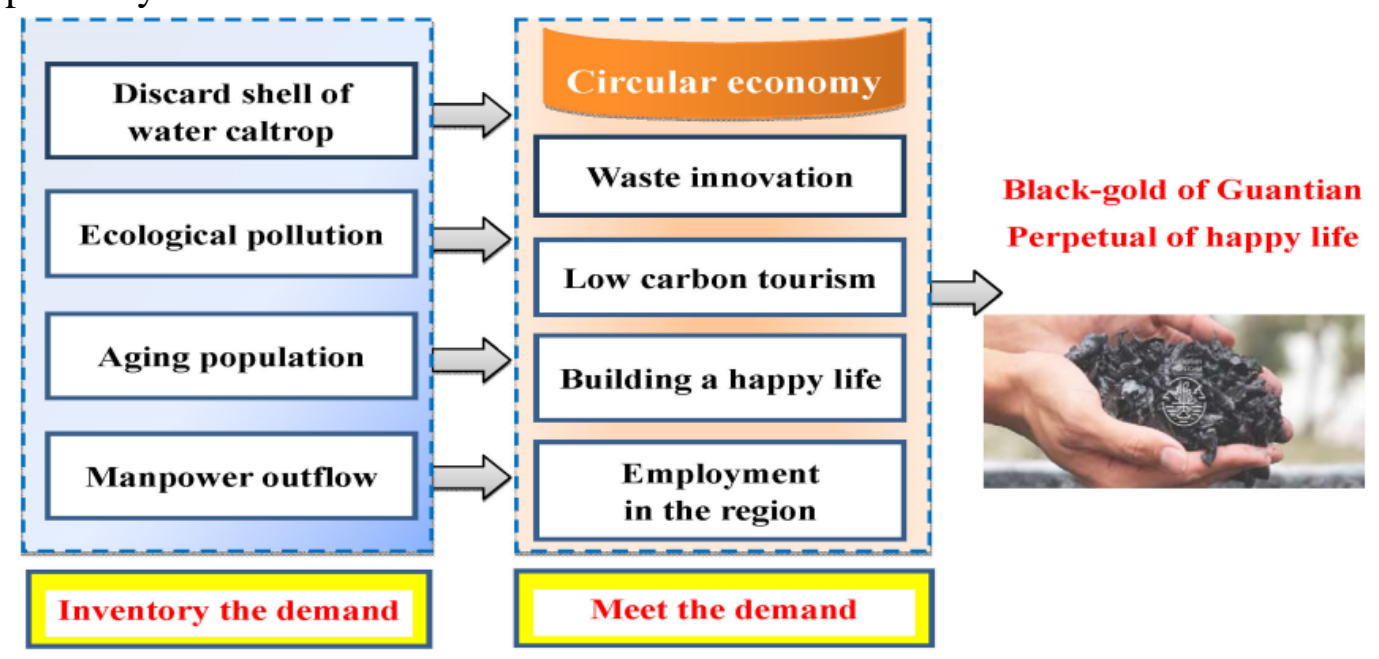

Figure 2. Overall architecture of the USR project.

\section{Core Concept of USR Project}

After the USR project team members brainstorming with stakeholders of Guantian district. Concluded that the core concept of circular economy of the USR project can be focus on the water caltrop, and divided into resource sharing, idea approbate, regional alliance, regional use, production biochar at region, and use regional material.

The water caltrop shell biochar has many good physical and chemical properties. Furthermore, the carbonation system and facility of water caltrop shell biochar is very simple and cheap, and only need a small site.

Therefore, the USR project was focus on derivative use of the water caltrop and water caltrop shell biochar. Based on the circular economy concept, the strategies and actions were developed.

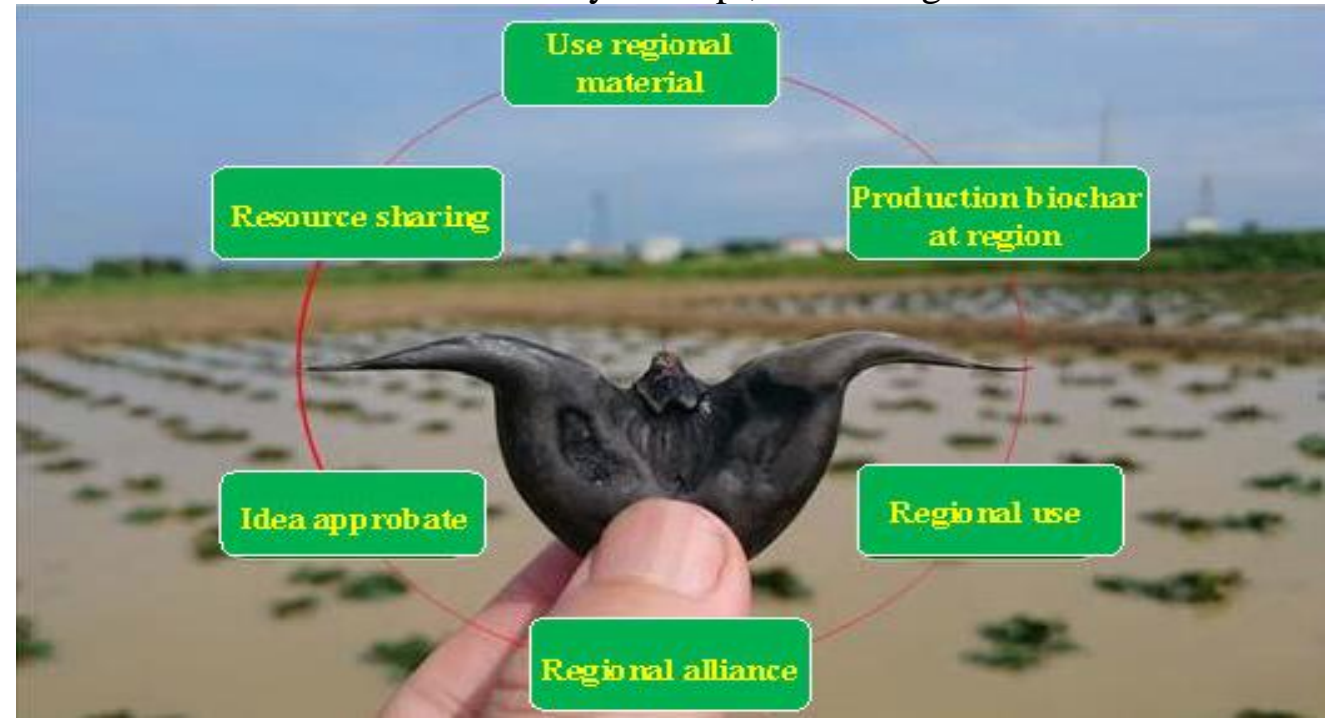

Figure 3. Circular economy concept of USR project. 


\section{Strategies and Action Plan}

The strategies and actions based on the core concept of circular economy were described which can be conduct to solve the 4 main problems were described below and Figure 4:

(1) Waste innovation: The core concept of this strategy is using water caltrop shell as fuel and using water caltrop shell biochar as fertilizer, the action plan includes promote friendly environmental farming methods, counseling to set up a biochar park, carbonization furnace operation training, and promote using water caltrop shell biochar as fertilizer.

(2) Low carbon tourism: The core concept of this strategy is to develop tourism course, the action plan includes training eco-tourism guider, food-agriculture and ecological education, DIY and Guantian kiln cooking experience, and held a journalist seminar of low carbon tourism.

(3) Employment in the region: The core concept of this strategy is to create career opportunities, the action plan includes setup FaceBook website and LINE channel, counseling mascot design, establish $\mathrm{O} 2 \mathrm{O}$ marketing channel, and strengthen Guantian black-gold brand image.

(4) Building a happy life: The core concept of this strategy is to improve the happiness of communities people, especially for the elders, the action plan includes test site at Palin community of Guantian district, training elders as guiders, cultural and creative commodity, and training the elderly to operate the Guantian kiln.
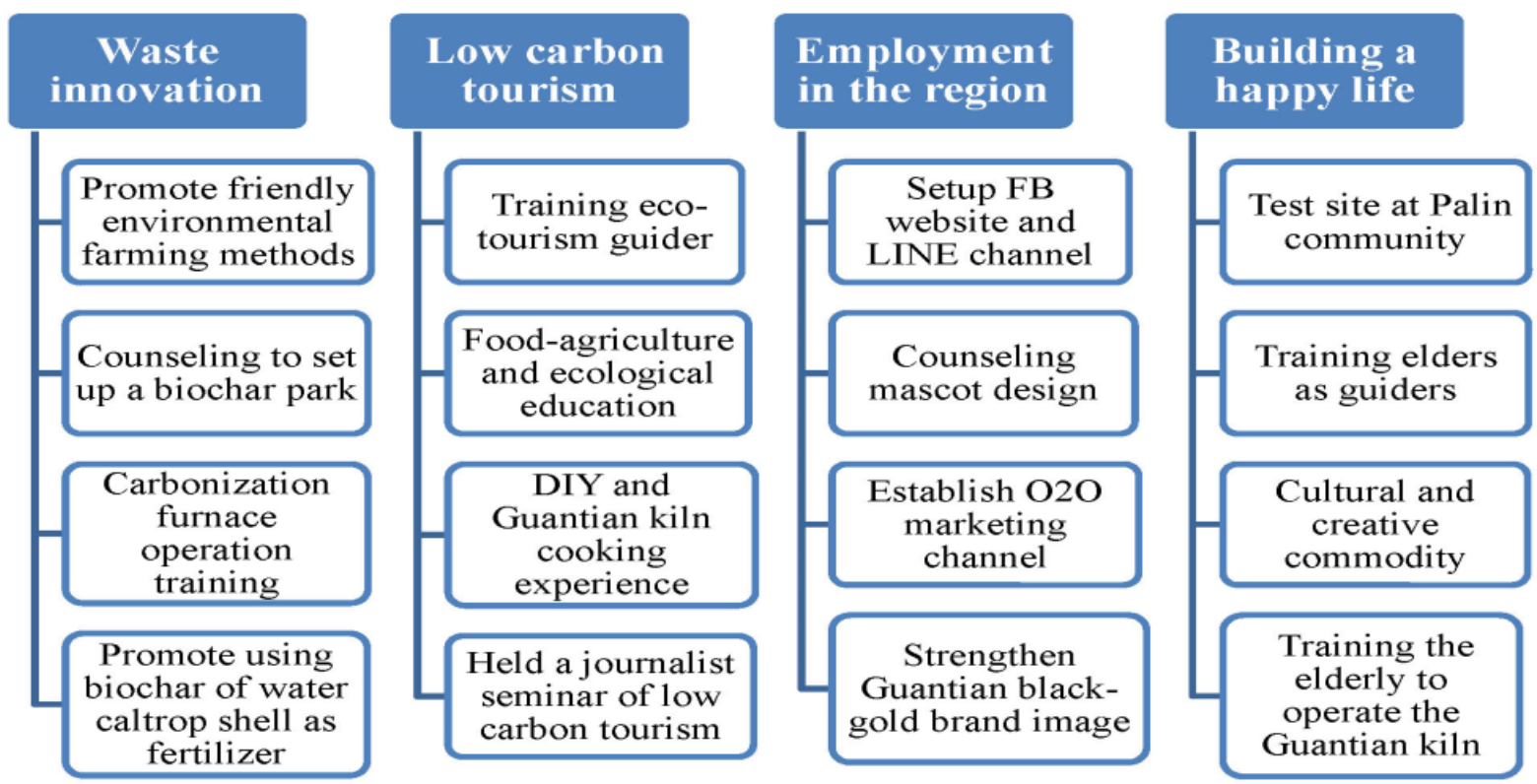

Figure 4. The 4 main strategies and actions of USR project.

To ensure the USR project succeed, except the USR team members and stakeholders of Guantian district, the supporting system also includes the public sectors: environmental protection agency, economic development board, and tourism bureau of Tainan city. The technology owner of the biochar production was also included.

Section 4 illustration the implement of the IMT model which carry out in department of Business Administration of KSU.

\section{IMT MODEL}

A new course "business ethics" was set up which cooperate with PBL and the USR project. The PBL problem topics were using the 4 main problems of the USR project. The teaching mode is consisted with the indoor and outdoor activities. The indoor activity through the teaching mode of PBL, students conduct group study, group discussion, reflection and assist counsel under the 
guidance of teachers. And enhance students' cooperative learning and interactive communication experience. The outdoor activity is combined with the USR project, and the group students independently promote the social practice in the field. The students also learn from the course activities how to communicate with each other, assign work and group spirit.

After the "business ethics" course, the students participating the 2018 national university ethical case analysis and micro film competition in Taiwan, and won the fifth place prize of the microfilm and the fourth place prize of the case analysis.

\section{CONCLUSION AND SUGGESTIONS}

After two years empirical, the water caltrop shell biochar showed that can be using as fertilizer and increase the rice harvest about 30\%. Furthermore, the rice is very delicious and won the THAIFEX TREND competition of organic products (Figure 6-1). The water caltrop shell biochar also can be made into deodorizing and odor adsorption package (Figure 6-2).
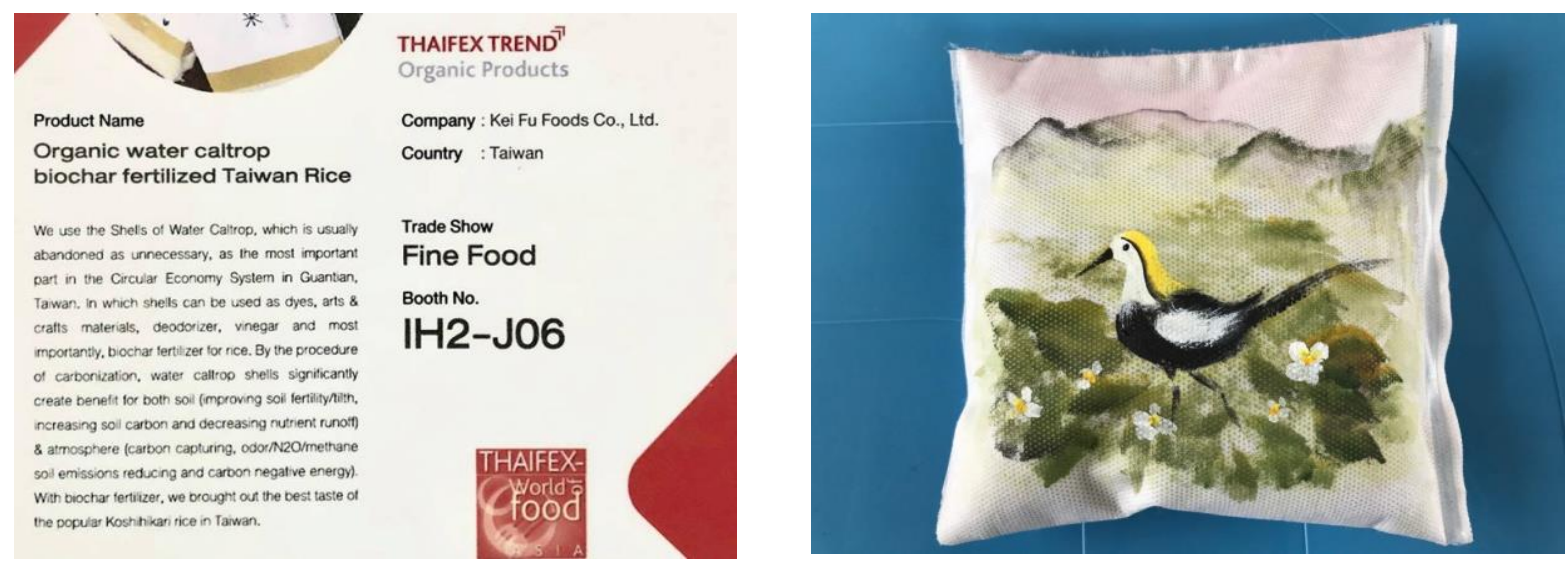

Figure 5-1. Rice using water caltrop shell biochar as fertilizer. (left).

Figure 5-2. Deodorizing and odor adsorption package. (right).

The were also had active of low carbon tourism to community people, the operation teaching active to students of the Guantian kiln, the building a happy life for the elders, and teaching the community elderly to make small potted plants used the water caltrop shell biochar to filter water.

This study aimed to develop an IMT model which included USR, PBL, teachers, and students through performed a USR project. After two years executed, the results showed the IMT model can achieve the expectation of the USR project. This USR project is also match with the 1, 2, 3, 8,12 and 17 of the UN's sustainable development goals. Furthermore, the students who participated in the USR project team resulted in better learning motivation, sense of accomplishment, and sense of honour.

This USR project also established a cooperative for the purpose of sustainable development of Guantian district. The cooperative can increase more than 20 employment opportunity, furthermore, through the cooperative marketing channel can help the sold of the cultural creative commodities, such as deodorizing and odor adsorption package and cultural creative doll of water caltrop which made by the community people. 


\section{REFERENCES}

Ayala-Rodríguez, N., Barreto, I., Ossandón, G.R., Castro A. \& Moreno, S. (2019). "Social transcultural representations about the concept of university social responsibility". Studies in Higher Education, 44(2), 245-259.

Barrows, H.S. (1996). "Problem-based learning in medicine and beyond: a brief overview". New Directions for Teaching and Learning, 68, 3-12.

Bowen, H. R. (1953). Social responsibilities of the businessman, Harper \& Row, New York.

Carroll, A.B. (1979). "A three-dimensional conceptual model of corporate performance". The Academy of Management Review, 4(4), 497-505.

Davis, K. (1963). "Can business afford to ignore social responsibilities?". California Management Review, 2(3), 70-76.

Esfijani, A., Hussain, F.K. \& Chang, E. (2013). "University social responsibility ontology". Engineering Intelligent Systems, 4, 271-281.

Perdiguero, T. (2006). "Responsabilidad Social de Las Empresas En Un Mundo Global". Social Responsibility of Companies in a Global World, Barcelona: Anagrama. (Cited from Ayala-Rodríguez et al., 2019).

Reiser, G.J. (2007). "Managing university social responsibility (USR)". in International Sustainable Campus Network: Best Practices-Future Challenges.

Sánchez-Hernández, M.I. \& Mainardes, E.W. (2016). "University social responsibility: a student base analysis in Brazil". International Review on Public and Nonprofit Marketing, 13, 151-169.

Stewart, B.L. (2004). "Online learning: a strategy for social responsibility in educational access". The Internet and Higher Education, 7(4), 299-310.

Vallaeys, F., de la Cruz, C. \& Sasia, P.M. (2009). "Responsabilidad social universitaria, Manual De Primeros Pasos". Banco Interamericano de Desarrollo. http:// blog.pucp.edu.pe/ item/ 122076/ manual-de-primeros-pasos-en-responsabilidad-social-universitaria.

Vasilescu, R., Barna, C., Epure, M. \& Baicu, C. (2010). "Developing university social responsibility: a model for the challenges of the new civil society". Procedia-Social and Behavioral Sciences, 2(2), 4177-4182.

Wartick, S. L. \& Cochran, P. L. (1985). "The evolution of the corporate social performance model". The Academy of Management Review, 10(4), 758-769.

Wigmore-Alvarez, A. \& Ruiz-Lozano, M. (2012). "University social responsibility (USR) in the global context: An overview of literature". Business \& Professional Ethics Journal, 31(34), 475-498.

Wood, D.F. (2003). "ABC of learning and teaching in medicine”. British Medical Journal, 326, 328-330. 